\title{
Phytochemicals in avocado peel and their potential uses
}

\author{
Sadiye AKAN
}

Cite this article as:

Akan, S. (2021). Phytochemicals in avocado peel and their potential uses. Food and Health, 7(2), 138-149. https://doi.org/10.3153/FH21015

Muş Alparslan University, Faculty of Engineering and Architecture, Department of Food Engineering, Mus, Turkey

ORCID IDs of the authors:

S.A. 0000-0002-5508-5262

Submitted: 18.08 .2020

Revision requested: 27.11 .2020

Last revision received: 07.12 .2020

Accepted: 07.12.2020

Published online: 21.03 .2021

Correspondence: Sadiye AKAN

E-mail: sadiyeakan@gmail.com

\begin{abstract}
A large amount of avocado is produced every year, and processing of avocado results in the production of large quantities of peel, which is usually disposed as waste without any further application. Avocado peel is a rich source of diverse phytochemicals known as health-promoting compounds, and these compounds can be used to produce high economic value products. However, the amount and composition of phenolic compounds vary regarding different factors, such as level of ripening and maturation, growing conditions and the country of origin. Phenolics within avocado peel have been reported to exhibit antioxidant, antimicrobial and anti-inflammatory effects, and associated with extensive health benefits. Thus, it is of great importance to recover these compounds from the peel for usage in food and health industries. This review focuses on the phytochemical compounds together with main factors influencing their types and amounts in avocado peel, and the possible utilisation of this by-product in the food, pharmaceutical and some other industries.
\end{abstract}

Keywords: Phytochemical, Avocado, Peel, Bioactive compound, Recovery, Bio-source

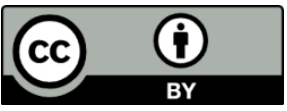

(C) 2021 The Author(s)

Available online at

http://jfhs.scientificwebjournals.com 


\section{Introduction}

Avocado is a significant tropical fruit with high amounts of bioactive components, and due to its health benefits, the consumption of avocado is increasing worldwide (Araújo et al., 2018; Migliore et al., 2018). The avocado has various consumption types and commercial uses in many products such as guacamole, chips, ice cream, frozen products, avocado paste, avocado oil and cosmetic products (Colombo \& Papetti, 2019; Palma et al., 2016; Saavedra et al., 2017). Nowadays, the usage of avocado as a functional ingredient for foods has gained remarkable interest. This is principally related with the bioactive compounds of avocado including unsaturated fatty acids, dietary fibre, vitamin C, B and E, lutein, pigments (carotenoids, chlorophylls, and anthocyanins), and phenolic compounds (Kosińska et al., 2012; Lu et al., 2005; Saavedra et al., 2017; Wang et al., 2010).

A great amount of avocado is generated every year and processing of avocado produces a considerable amount of byproducts (peel and seed) which account nearly $30 \%$ of the fresh weight of the fruit (Araújo et al., 2018; Figueroa et al., 2018; Melgar et al., 2018). Hereby, it produces by-products that cause environmental problems and are generally discarded without any additional applications (Araújo et al., 2018; Figueroa et al., 2018; Kosińska et al., 2012).

Avocado peel contains carbohydrates (62-73.3\%), proteins (4-8.3\%), lipids (4.4-9.1\%) and fibres (almost 50\%) and also it has great amount of bioactive compounds (Colombo \& Papetti, 2019). The peel is reported to contain high phenolic content and antioxidant activity. Besides this, the peel has been demonstrated to show effectual antimicrobial, antibiotic and anti-inflammatory properties (Adikaram et al., 1992; Morais et al., 2015). Within this scope, it is a promising material for the production of functional foods and pharmaceutical products, and also it can be used as a bio-source for the production of environment friendly adsorbents (Antasionasti et al., 2017; Kosińska et al., 2012; Palma et al., 2016).

Phytochemicals are important secondary metabolic compounds produced by plants and are present in large amounts in avocado peels compared to other fruit products (Figueroa et al., 2018; Morais et al., 2015). Polyphenols are the biggest class of the phytochemicals, which are known with varied and remarkable biological functions for human health (Sagar et al., 2018). Phenolic phytochemicals have been linked with multiple health benefits, such as antitumor, anti-aging, antidiabetic, antioxidant and anti-inflammatory properties (Ahangarpour et al., 2019; Lin et al., 2016; Lu et al., 2005; Saavedra et al., 2017). Due to their protective effects against oxidation and colour deterioration, and prevention of the growth of bacteria and moulds, they are extensively used in the food industry (Kosińska et al., 2012; Rodríguez-Carpena et al., 2011). Hence, the recovery of these bioactive products from avocado peel may lead to produce new products with added value and improve the usage of the by-products of avocado processing industry. For the efficient exploitation and valorisation of phytochemicals in avocado peel, it is important to understand the profile of chemicals (particularly individual phenolic compounds), factors influencing the amounts of phenolics in the peel, and potential utilisation of these compounds as food ingredients or other proposes. This review inclusively points out the phenolic compounds of avocado peel, highlights the uses in food industry and the potential uses for some other products.

\section{Botany and Production}

Avocado belongs to the family of Lauraceae which is a dicotyledonous evergreen plant, indigenous to Mexico, but recently produced and consumed worldwide (Álvarez et al., 2015; Hurtado-Fernández et al., 2018; Melgar et al., 2018). The word avocado is used by the Aztecs and derived from ahuacatl, while it is called by various names (aguacate, cupandra, avocatier, cura, abacate and palta) in different countries (Araújo et al., 2018; Yahia \& Woolf, 2011). It is also known as alligator pear, butter pear and vegetable pear (Hurtado-Fernández et al., 2018). Botanically, avocado is divided into 3 groups, with different terms as Mexican (Persea americana var. drymifolia), Guatemalan (Persea nubigena var. guatemalensis), and West Indian (Persea americana var. americana). The names are based upon the origins, the typical growing conditions and the properties of the fruit (Araújo et al., 2018; Yahia \& Woolf, 2011). There are a vast number of avocado varieties with the main cultivars such as Hass, Fuerte, Bacon, Reed, Gwen, Edranol, Ettinger, Pinkerton, Shepard, Zutano etc., among them, Hass and Fuerte varieties are the most popular varieties (Hurtado-Fernández et al., 2018; Mardigan et al., 2018; Yahia \& Woolf, 2011). 
Avocado is a berry, composed of a big seed at the central, and pericarp which contains skin (exocarp), the edible part (mesocarp) and the covering layer of the seed (endocarp) with different weights range from $120 \mathrm{~g}$ and $2.5 \mathrm{~kg}$, rough or smooth surface, thick or thin skin, oval to round shape (Araújo et al., 2018; Hurtado-Fernández et al., 2018). Avocado has a specific feature of ripening as it does not ripen on the tree; but ripening process starts after harvesting which needs 5 to 7 days at room temperature. Avocado pread all over the world especially in tropical and subtropical regions. 'Hass' variety, a Mexican strain, is the most important, wellrecognized and commercially important type (Wang et al., 2010).

Avocado is known as a healthy product because of its high nutritional and phytochemical content (Yahia \& Woolf, 2011). Accordingly, its production in the world has been increased continually between 1995 (2217521 million tonnes) and 2018 (6407171 million tonnes) and it is produced by more than 100 countries. Mexico has remained the main producer because its production accounts for approximately $34 \%$ of total production of avocados and it is also the leading exporter (FAOSTAT, 2018). Americas is the largest avocado producing continent with about $74 \%$ of the total production, it is followed by Africa then Asia (Figure 1.). Recently, the demand of avocado for food and nutraceutical industries has been rising owing to its before-mentioned characteristics (Hurtado-Fernández et al., 2018). Avocado is getting more attention also in Turkey. The plantation of avocado in Turkey dates back to the beginning of 1970s with the trials of Hass,
Fuerte, Zutano and Bacon varieties (brought from California via FAO) in Antalya, Dalaman, Alata, Adana and Iskenderun (Bayram, 2005). The production capacity of avocado in Turkey between 1995 and 2018 years has been scaled up from 153 tonnes to 3164 tonnes, and the production capacity has been doubled between 2013 and 2018 (FAOSTAT., 2018). In brief, as can be understood from the production statistics, avocado production tends to increase in the future.

\section{Phytochemicals of Avocado Peel}

Avocado peel is a rich source of phytochemicals (Table 1) regarding their total phenolic content range from 0.6 to 6.8 $\mathrm{mg}$ gallic acid equivalent/g sample (mg GAE/g sample) for the fresh avocado peel, and between the interval of 4.3-120.3 $\mathrm{mg} \mathrm{GAE} / \mathrm{g}$ for the dry avocado peel with the inter-varietal alterations. The peel, accounts for around $18 \%$ of the total fresh weight, which contains higher phenolic content and antioxidant activity than the reported values in the edible part (pulp) (Melgar et al., 2018; Rotta et al., 2016; Tremocoldi et al., 2018; Wang et al., 2010). When compared to other tropical fruit peels (banana, melon, passion fruit, papaya, pineapple and watermelon), avocado dried peel has the highest total phenolic content and the raw peel of the fruit presents the highest flavonoid content. Furthermore, dried avocado peel shows the highest antioxidant activity (FRAP assay) with the comparison of the peels of other fruits (Morais et al., 2015). The phenolic content and antioxidant activity of avocado peel are several-fold higher than the values reported for raw blueberries for their high antioxidant activity (Kosińska et al., 2012; López-Cobo et al., 2016; Wang et al., 2010).

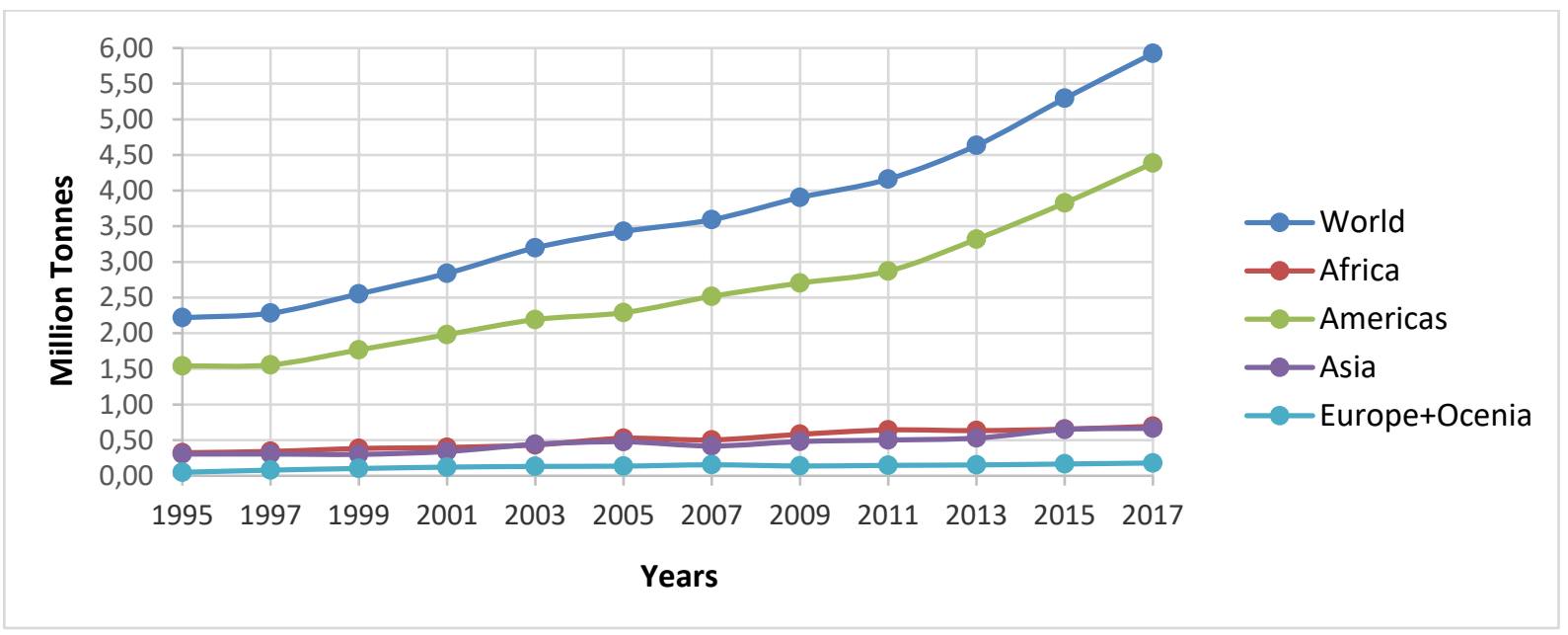

Figure 1. Avocado production of the world by years (FAOSTAT, 2017). 
Table 1. Total phenolic content and antioxidant activities of avocado peel

\begin{tabular}{|c|c|c|c|c|c|c|c|c|c|}
\hline Cultivars & Region & $\begin{array}{l}\text { Fresh or } \\
\text { dry subs- } \\
\text { tance }\end{array}$ & $\begin{array}{l}\text { Total pheno- } \\
\text { lic compo- } \\
\text { unds }\end{array}$ & $\mathrm{DPPH}^{\mathrm{i}}$ & $\mathrm{ABTS}^{\mathrm{j}}$ & ORAC $^{k}$ & FRAP $^{1}$ & Extraction method & Reference \\
\hline Hass & Australia & Dry & $25.3^{\mathrm{a}}$ & - & $161.0^{\mathrm{e}}$ & $470.0^{\mathrm{e}}$ & - & $\begin{array}{l}\text { Methanol }(80 \%) \text { extraction with } \\
\text { solid to solvent ratio } 1: 8 \text { in a } \\
\text { shaking water bath at } 60{ }^{\circ} \mathrm{C}\end{array}$ & $\begin{array}{l}\text { (Kosińska et } \\
\text { al., 2012) }\end{array}$ \\
\hline Shepard & Australia & Dry & $15.6^{\mathrm{a}}$ & - & $112.0^{\mathrm{e}}$ & $290.0^{\mathrm{e}}$ & - & & \\
\hline Slimcado & Florida & Dry & $4.6^{\mathrm{b}}$ & $39.7^{\mathrm{d}}$ & - & $58.2^{\mathrm{d}}$ & - & $\begin{array}{l}\text { Extraction with ace- } \\
\text { tone/water/acetic acid via vortex } \\
\text { and sonication }\end{array}$ & $\begin{array}{l}\text { (Wang et al., } \\
\text { 2010) }\end{array}$ \\
\hline Simmonds & Florida & Dry & $7.4^{\mathrm{b}}$ & $84.9^{\mathrm{d}}$ & - & $226.8^{\mathrm{d}}$ & - & & \\
\hline Loretta & Florida & Dry & $7.6^{\mathrm{b}}$ & $38.0^{\mathrm{d}}$ & - & $92.6^{\mathrm{d}}$ & - & & \\
\hline Choquette & Florida & Dry & $13.9^{\mathrm{b}}$ & $90.8^{\mathrm{d}}$ & - & $174.8^{\mathrm{d}}$ & - & & \\
\hline Booth 7 & Florida & Dry & $13.2^{\mathrm{b}}$ & $80.0^{\mathrm{d}}$ & - & $164.9^{\mathrm{d}}$ & - & & \\
\hline Booth 8 & Florida & Dry & $8.1^{\mathrm{b}}$ & $52.6^{\mathrm{d}}$ & - & $110.5^{\mathrm{d}}$ & - & & \\
\hline Tonnage & Florida & Dry & $4.3^{\mathrm{b}}$ & $51.9^{\mathrm{d}}$ & - & $187.6^{\mathrm{d}}$ & - & & \\
\hline Hass & Mexico & Dry & $12.6^{\mathrm{b}}$ & $189.8^{\mathrm{d}}$ & - & $631.4^{\mathrm{d}}$ & - & & (Rodríguez- \\
\hline Hass & Spain & Fresh & $90.0^{\mathrm{c}}$ & $89000^{\mathrm{d}}$ & - & - & - & NR & $\begin{array}{l}\text { Carpena et } \\
\text { al., 2011) }\end{array}$ \\
\hline Fuerte & Spain & Fresh & $60.8^{c}$ & $200000^{\mathrm{d}}$ & - & - & - & & \\
\hline NR & Brazil & Fresh & $1.8^{\mathrm{c}}$ & - & - & - & $27.8^{\mathrm{f}}$ & $\begin{array}{l}\text { Methanol extraction with solid } \\
\text { to solvent ratio } 1: 10\end{array}$ & $\begin{array}{l}\text { (Morais et al., } \\
\text { 2015) }\end{array}$ \\
\hline NR & Brazil & Dry & $12.5^{\mathrm{c}}$ & - & - & - & $441.8^{\mathrm{f}}$ & & \\
\hline Hass & Portugal & Fresh & $6.8^{\mathrm{b}}$ & - & - & - & - & NR & $\begin{array}{l}\text { (Vinha et al., } \\
\text { 2013) }\end{array}$ \\
\hline Hass & Brazil & Dry & $63.5^{\mathrm{b}}$ & $310.0^{\mathrm{e}}$ & $791.5^{\mathrm{e}}$ & - & $1175.1^{\mathrm{g}}$ & $\begin{array}{l}\text { Extraction with ace- } \\
\text { tone/water/acetic acid via vortex } \\
\text { and sonication }\end{array}$ & $\begin{array}{l}\text { (Tremocoldi } \\
\text { et al., 2018) }\end{array}$ \\
\hline Fuerte & Brazil & Dry & $120.3^{b}$ & $420.0^{\mathrm{e}}$ & $1004.5^{\mathrm{e}}$ & - & $1881.4^{\mathrm{g}}$ & & \\
\hline NR & Brazil & Fresh & $0.6^{\mathrm{b}}$ & $16.1^{\mathrm{d}}$ & - & - & $9.6^{\mathrm{h}}$ & NR & $\begin{array}{l}\text { (Rotta et al., } \\
2016 \text { ) }\end{array}$ \\
\hline NR & Brazil & Dry & $10.8^{\mathrm{b}}$ & $763.0^{\mathrm{d}}$ & - & - & $422.8^{\mathrm{h}}$ & NR & \\
\hline
\end{tabular}

NR: not reported.

${ }^{\mathrm{a}} \mathrm{mg}$ catechin equivalent/g DM.

${ }^{\mathrm{b}} \mathrm{mg} \mathrm{GAE} / \mathrm{g}$ sample.

${ }^{c} \mathrm{mg} \mathrm{GAE} / \mathrm{g}$ DM.

d $\mu \mathrm{mol} \mathrm{TE} / \mathrm{g}$.

${ }^{\mathrm{e}} \mu \mathrm{mol} \mathrm{TE} / \mathrm{g} \mathrm{DM}$.

${ }^{\mathrm{f}} \mu \mathrm{mol} \mathrm{FeSO} / \mathrm{g} \mathrm{DM}$.

$\mathrm{g}_{\mu \mathrm{mol} \mathrm{Fe}}^{2+} / \mathrm{g} \mathrm{DM}$.

h $\mu \mathrm{mol} \mathrm{FeSO} 4.7 \mathrm{H}_{2} \mathrm{O} / \mathrm{g} \mathrm{DM}$.

i 2,2-Diphenyl-1-picrylhydrazyl.

j 2,2'-azino-bis(3-ethylbenzothiazoline-6-sulphonic acid).

${ }^{\mathrm{k}}$ oxygen radical absorbance capacity.

${ }^{1}$ ferric reducing antioxidant power. 
Previous studies have reported that avocado peel contains more than 30 individual phenolic compounds and high polymeric compounds which can be extensively categorized into 3 groups; hydroxycinnamic acids (Table 2), flavonols (Table 2) and flavan-3-ols (Table 3). 5-O-caffeoylquinic acid, also known as chlorogenic acid, is the ester produced from cinnamic acids and quinic acid which is the main hydroxycinnamic acid in avocado peel. It exhibits anti-hyperglycaemic effects, greater DPPH activity than vitamin E, and it is also effective for the prevention of oxidation and formation of free radicals (Ahangarpour et al., 2019; Karasawa \& Mohan, 2018; López-Cobo et al., 2016). Between the identified flavonols, the derivatives of quercetin were the dominating compounds (Kosińska et al., 2012; López-Cobo et al., 2016; Melgar et al., 2018). Flavonols are one of the biggest class of the flavonoids mainly gather in the peel of the fruits and associated with the control of oxidation, inflammation and protection against cardiac diseases (Figueroa et al., 2018).

The leading group of phenolics determined in avocado peel is flavan-3-ols ((epi)catechin derivatives) (Table 3) which comprises monomers, dimers and polymers (Melgar et al., 2018). Catechin, epicatechin, and A- and B-type dimers are subgroups of procyanidins (Wang et al., 2010). The oligomers and polymers, known as procyanidins, are one of the largest phenolic compounds in the food products which have been studied to propose prevention of cancer, inflammation and some chronic diseases (Mark et al., 2019; Wang et al., 2010). It is reported that the procyanidin level of avocado peel is comparable to the one determined in natural cocoa powder which have been declared to have great procyanidin amount. The primary procyanidins in avocado peel are in B-type. As avocado peel contains A-type procyanidins, it may lead to have some other health benefits such as preventing the infections of urinary tract, and also procyanidins were reported to be the main polyphenols that made contribution to the antioxidant activity of avocado peel. Chlorophylls, the pigments with potential antioxidant activities, are found in avocado peel, but they are not the dominant antioxidant compounds in avocado peel because of the weak correlation between pigment concentration and antioxidant activity (Wang et al., 2010).

\section{Main Factors Affecting the Type and Amount of Phytochemicals in Avocado Peel}

The type and amount of individual and total phenolics in avocado peel change according to some factors, such as the degree of maturation and ripening, variety, conditions of cultivation and the country of plant growth (Golukcu \& Ozdemir, 2010; Hurtado-Fernández et al., 2018; Kosińska et al., 2012; Ozdemir \& Topuz, 2004). For instance, among 8 different cultivars (Slimcado, Simmonds, Loretta, Choquette, Booth 7 , Booth 8, Tonnage and Hass), Hass variety is reported to have the highest phenolic content (51.6 mg GAE/g) and ranked as the third highest antioxidant activity by the ORAC assay $(428.8 \mu \mathrm{mol} \mathrm{TE} / \mathrm{g})$ in the peels with comparison to other varieties (Wang et al., 2010). Kosińska et al. (2012) compared the phenolic content and antioxidant capacities of 2 different varieties (Hass and Shepard) of avocado peels and reported significant variations among the varieties. To exemplify, $(+)-$ catechin and procyanidin dimers were not detected in the peel of the Shepard cultivar, whereas they were found in the peel of Hass cultivar. Caffeoylquinic acid and quercetin derivatives were identified in the peels of both varieties. In another study, the difference of total phenolic content among 'Hass' and 'Fuerte' varieties were investigated and the results revealed that the peels of Fuerte variety has higher total phenolic content (120.3 $\mathrm{mg} \mathrm{GAE} / \mathrm{g}$ of dry avocado) than Hass variety (63.5 mg GAE/g of dry avocado) (Tremocoldi et al., 2018).

The colour and texture of avocado peel alter during the maturation stage, which cause changes in the types and amounts of phenolic and anti-fungal compounds (Bowen et al., 2018; Yahia \& Woolf, 2011). The persin content of 'Hass' avocado peel was found to decrease apparently throughout the maturation stage, over ripened peel had nearly $30 \%$ less than total persin (the sum of persin and persenone-A) when the persin content was about $600 \mathrm{mg} / \mathrm{kg}$ at the early harvest period and $400 \mathrm{mg} / \mathrm{kg}$ at the late harvest period, almost 4 months later. Whilst ripening and storage, the concentrations decreased as well, however the degree of variation was depending upon the harvest concentration. The epicatechin and total (epi)-catechin (the sum of epicatechin and catechin monomers, epicatechin dimer B2, and (epi)-catechin oligomers) content reduced between the early and late harvest periods, while the changes regarding maturation were greater than the ones in storage and ripening (Bowen et al., 2018). 
Table 2. Identified hydroxycinnamic acids and flavonols in avocado peel of different cultivars

\begin{tabular}{|c|c|c|c|}
\hline Phenolic compounds & Cultivars & Quantity & Reference \\
\hline \multicolumn{4}{|l|}{ Hydroxycinnamic acids: } \\
\hline \multirow[t]{4}{*}{ 5-O-caffeoylquinic acid } & Hass & $81.8 \mu \mathrm{g} / \mathrm{g} \mathrm{DM}$ & (Kosińska et al., 2012) \\
\hline & Shepard & $77.4 \mu \mathrm{g} / \mathrm{g} \mathrm{DM}$ & \\
\hline & Hass & $22.7 \mathrm{mg} / \mathrm{g}$ extract ${ }^{\mathrm{a}}$ & (Melgar et al., 2018) \\
\hline & Hass & - & (López-Cobo et al., 2016) \\
\hline 4-O-Caffeoylquinic acid & Hass & $20.2 \mathrm{mg} / \mathrm{g}$ extract $\mathrm{t}^{\mathrm{a}}$ & (Melgar et al., 2018) \\
\hline quinic acid & Hass & - & (López-Cobo et al., 2016) \\
\hline \multicolumn{4}{|l|}{ Flavonols: } \\
\hline quercetin-3,4'-diglucoside & Hass & $46.1 \mu \mathrm{g} / \mathrm{g} \mathrm{DM}$ & (Kosińska et al., 2012) \\
\hline quercetin 3-O-rutinoside & Hass & $23.8 \mu \mathrm{g} / \mathrm{g} \mathrm{DM}$ & (Kosińska et al., 2012) \\
\hline \multirow[t]{2}{*}{ quercetin-3-O-arabinosyl-glucoside } & Hass & $80.4 \mu \mathrm{g} / \mathrm{g} \mathrm{DM}$ & (Kosińska et al., 2012) \\
\hline & Hass & - & (López-Cobo et al., 2016) \\
\hline quercetin-3-O-arabinoside & Shepard & $94.1 \mu \mathrm{g} / \mathrm{g} \mathrm{DM}$ & (Kosińska et al., 2012) \\
\hline \multirow[t]{2}{*}{ quercetin 3-O-galactoside } & Hass & $31.2 \mu \mathrm{g} / \mathrm{g} \mathrm{DM}$ & (Kosińska et al., 2012) \\
\hline & Shepard & $144.1 \mu \mathrm{g} / \mathrm{g} \mathrm{DM}$ & (Kosińska et al., 2012) \\
\hline \multirow[t]{2}{*}{ quercetin-3-O-glucoside } & Shepard & $54.6 \mu \mathrm{g} / \mathrm{g} \mathrm{DM}$ & (Kosińska et al., 2012) \\
\hline & Hass & $1.2 \mathrm{mg} / \mathrm{g}$ extract ${ }^{\mathrm{a}}$ & (Melgar et al., 2018) \\
\hline quercetin derivative (I) & Shepard & $63.7 \mu \mathrm{g} / \mathrm{g} \mathrm{DM}$ & (Kosińska et al., 2012) \\
\hline quercetin derivative (II) & Hass & $62.5 \mu \mathrm{g} / \mathrm{g} \mathrm{DM}$ & (Kosińska et al., 2012) \\
\hline quercetin derivative (III) & Shepard & $81.9 \mu \mathrm{g} / \mathrm{g} \mathrm{DM}$ & (Kosińska et al., 2012) \\
\hline quercetin-diglucoside & Hass & - & (López-Cobo et al., 2016) \\
\hline rutin & Hass & - & (López-Cobo et al., 2016) \\
\hline quercetin-dihexoside & Hass & $1.4 \mathrm{mg} / \mathrm{g}$ extract $^{\mathrm{a}}$ & (Melgar et al., 2018) \\
\hline quercetin-pentoside-hexoside & Hass & $1.5 \mathrm{mg} / \mathrm{g}$ extract $^{\mathrm{a}}$ & (Melgar et al., 2018) \\
\hline quercetin-glucoronide & Hass & $1.2 \mathrm{mg} / \mathrm{g}$ extract ${ }^{\mathrm{a}}$ & (Melgar et al., 2018) \\
\hline quercetin-hexoside & Hass & $1.1 \mathrm{mg} / \mathrm{g}$ extract ${ }^{\mathrm{a}}$ & (Melgar et al., 2018) \\
\hline quercetin-rhamnoside-hexoside & Hass & $1.2 \mathrm{mg} / \mathrm{g}$ extract ${ }^{\mathrm{a}}$ & (Melgar et al., 2018) \\
\hline quercetin-rhamnoside-pentoside & Hass & $1.0 \mathrm{mg} / \mathrm{g}$ extract ${ }^{\mathrm{a}}$ & (Melgar et al., 2018) \\
\hline isorhametin-glucuronide & Hass & $1.1 \mathrm{mg} / \mathrm{g}$ extract ${ }^{\mathrm{a}}$ & (Melgar et al., 2018) \\
\hline
\end{tabular}

${ }^{a}$ reported for ethanolic extracts. 
Table 3. Identified flavan-3-ols and pigments in avocado peel of different cultivars

\begin{tabular}{|c|c|c|c|}
\hline Phenolic compounds & Cultivars & Quantity & Reference \\
\hline $\begin{array}{l}\text { Flavan-3-ol monomers: } \\
\text { catechin }\end{array}$ & Hass & $148.8 \mu \mathrm{g} / \mathrm{g} \mathrm{DM}$ & (Kosińska et al., 2012) \\
\hline \multirow[t]{3}{*}{ epicatechin } & Hass & $46.5 \mathrm{mg} / \mathrm{g}$ extract ${ }^{\mathrm{a}}$ & (Melgar et al., 2018) \\
\hline & NR (raw peel) & $1.8 \mu \mathrm{g} / 100 \mathrm{~g} \mathrm{DM}$ & (Morais et al., 2015) \\
\hline & NR (dried peel) & $1.3 \mu \mathrm{g} / \mathrm{g} \mathrm{DM}$ & (Morais et al., 2015) \\
\hline \multirow[t]{2}{*}{ catechin hydrate } & NR (raw peel) & $3.00 \mu \mathrm{g} / 100 \mathrm{~g} \mathrm{DM}$ & (Morais et al., 2015) \\
\hline & NR (dried peel) & $1.7 \mu \mathrm{g} / \mathrm{g} \mathrm{DM}$ & (Morais et al., 2015) \\
\hline \multicolumn{4}{|l|}{ Flavan-3-ol dimers: } \\
\hline procyanidin dimer B (I) & Hass & $135.4 \mu \mathrm{g} / \mathrm{g} \mathrm{DM}$ & (Kosińska et al., 2012) \\
\hline procyanidin dimer $\mathrm{A}$ & Hass & $26.8 \mu \mathrm{g} / \mathrm{g} \mathrm{DM}$ & (Kosińska et al., 2012) \\
\hline procyanidin dimer B (II) & Hass & $55.1 \mu \mathrm{g} / \mathrm{g} \mathrm{DM}$ & (Kosińska et al., 2012) \\
\hline B-type (epi)catechin dimer & Hass & $34.1 \mathrm{mg} / \mathrm{g}$ extract ${ }^{\mathrm{a}}$ & (Melgar et al., 2018) \\
\hline \multicolumn{4}{|l|}{ Flavan-3-ol polymers: } \\
\hline B-type (epi)catechin trimer & Hass & $26.2 \mathrm{mg} / \mathrm{g}$ extract ${ }^{\mathrm{a}}$ & (Melgar et al., 2018) \\
\hline B-type (epi)catechin tetramer & Hass & $21.2 \mathrm{mg} / \mathrm{g}$ extract ${ }^{\mathrm{a}}$ & (Melgar et al., 2018) \\
\hline B-type (epi)catechin pentamer & Hass & $16.6 \mathrm{mg} / \mathrm{g}$ extract ${ }^{\mathrm{a}}$ & (Melgar et al., 2018) \\
\hline \multicolumn{4}{|l|}{ Pigments: } \\
\hline \multirow[t]{8}{*}{ Chlorophyll $\alpha$} & Slimcado & $0.1 \mu \mathrm{g} / \mathrm{g}$ & (Wang et al., 2010) \\
\hline & Simmonds & $0.5 \mu \mathrm{g} / \mathrm{g}$ & (Wang et al., 2010) \\
\hline & Loretta & $0.4 \mu \mathrm{g} / \mathrm{g}$ & (Wang et al., 2010) \\
\hline & Choquette & $1.1 \mu \mathrm{g} / \mathrm{g}$ & (Wang et al., 2010) \\
\hline & Booth 7 & $0.9 \mu \mathrm{g} / \mathrm{g}$ & (Wang et al., 2010) \\
\hline & Booth 8 & $0.9 \mu \mathrm{g} / \mathrm{g}$ & (Wang et al., 2010) \\
\hline & Tonnage & $1.1 \mu \mathrm{g} / \mathrm{g}$ & (Wang et al., 2010) \\
\hline & Hass & $21.0 \mu \mathrm{g} / \mathrm{g}$ & (Wang et al., 2010) \\
\hline \multirow[t]{8}{*}{ Chlorophyll $\beta$} & Slimcado & $0.1 \mu \mathrm{g} / \mathrm{g}$ & (Wang et al., 2010) \\
\hline & Simmonds & $0.8 \mu \mathrm{g} / \mathrm{g}$ & (Wang et al., 2010) \\
\hline & Loretta & $0.7 \mu \mathrm{g} / \mathrm{g}$ & (Wang et al., 2010) \\
\hline & Choquette & $2.0 \mu \mathrm{g} / \mathrm{g}$ & (Wang et al., 2010) \\
\hline & Booth 7 & $1.3 \mu \mathrm{g} / \mathrm{g}$ & (Wang et al., 2010) \\
\hline & Booth 8 & $1.7 \mu \mathrm{g} / \mathrm{g}$ & (Wang et al., 2010) \\
\hline & Tonnage & $1.9 \mu \mathrm{g} / \mathrm{g}$ & (Wang et al., 2010) \\
\hline & Hass & $20.2 \mu \mathrm{g} / \mathrm{g}$ & (Wang et al., 2010) \\
\hline
\end{tabular}

NR: not reported.

${ }^{a}$ reported for ethanolic extracts. 
Regarding drying as a pre-treatment method; different temperatures, airflow rate and loading density in convective drying have differential effects on total phenolic content of avocado peel. The increment in the drying temperature and air flow rate gives rise to decrease in total phenolic content of avocado peel (Saavedra et al., 2017). On the other hand, different drying methods such as oven drying and lyophilisation have variable effects on the phenolic content of avocado peel. Total phenolic content was found to decline with lyophilisation treatment, while it was increasing with oven drying process. Further, both lyophilisation and oven drying lead to decrease in the flavonoid content of avocado peel when compared to the raw samples. As regards to individual phenolic compounds subjected to the same drying conditions, some of them increased while others decreased (Morais et al., 2015). Heat treatment may cause different reactions on the phenolic compounds of avocado peel. Application of heat can be regarded as an effective technique in liberation of the bonds of phytochemicals to the free forms, which may result in the increase in the total phenolic content and antioxidant activity.
Nevertheless, the application of heat may also trigger destroying of heat sensitive phenolic compounds resulting in the loss of these compounds (Shodehinde \& Oboh, 2013).

\section{Potential Uses of Avocado Peel in the Food, Pharmaceutical and Some Other Industries}

Processing of avocado generates a huge amount of peel and causes the loss of phytochemically rich materials of have high economic value (Colombo \& Papetti, 2019; Coman et al., 2020; Permal et al., 2020). Avocado peel is traditionally used for livestock feed (Figueroa et al., 2018). Nonetheless, avocado peel contains important compounds for food, pharmaceutical and other industries as it has higher phenolic content than the pulp and seed (Kosińska et al., 2012; Rotta et al., 2016; Tremocoldi et al., 2018). For these reasons, recently, avocado peel has been drawing more attention and being investigating more extensively. The research reported on the valorisation of avocado peel are summarized in Table 4 .

Table 4. Potential applications of avocado peel and its bioactive compounds in the food and pharmaceutical industries

\begin{tabular}{|c|c|c|c|}
\hline The type of material & Functions & Usage/Potential usage & Reference \\
\hline Dried avocado peel & Strong antioxidant activity & $\begin{array}{l}\text { Production of phenolic compounds isolates } \\
\text { and concentrates }\end{array}$ & (Saavedra et al., 2017) \\
\hline $\begin{array}{l}\text { Avocado peel extracted } \\
\text { with acetone/water }\end{array}$ & $\begin{array}{l}\text { Prevention of various oxida- } \\
\text { tion reactions }\end{array}$ & $\begin{array}{l}\text { Protection of raw porcine patties against dif- } \\
\text { ferent types of oxidation reactions }\end{array}$ & $\begin{array}{l}\text { (Rodríguez-Carpena et al., } \\
\text { 2011) }\end{array}$ \\
\hline $\begin{array}{l}\text { Lyophilised avocado } \\
\text { peel }\end{array}$ & Strong antioxidant activity & $\begin{array}{l}\text { Food preservative or an ingredient for func- } \\
\text { tional foods }\end{array}$ & (Kosińska et al., 2012) \\
\hline $\begin{array}{l}\text { Avocado peel extracted } \\
\text { with various solvents }\end{array}$ & Strong antioxidant activity & Food preservative as an antioxidant & (Antasionasti et al., 2017) \\
\hline $\begin{array}{l}\text { Avocado peel extracted } \\
\text { with various solvents }\end{array}$ & $\begin{array}{l}\text { Strong antioxidant and anti-in- } \\
\text { flammatory activities }\end{array}$ & Food supplement and functional food & (Tremocoldi et al., 2018) \\
\hline Avocado peel & $\begin{array}{l}\text { Strong antioxidant and antimi- } \\
\text { crobial activity }\end{array}$ & Food additive as antioxidant and antimicrobial & (Ortiz-Viedma et al., 2018) \\
\hline Dried avocado peel & Strong antioxidant activity & Usage in tea production & (Rotta et al., 2016) \\
\hline Avocado peel & Adsorption capacity & Production of avocado carbon peel & (Devi et al., 2008) \\
\hline Avocado peel & Adsorption capacity & Production of carboneous material & (Palma et al., 2016) \\
\hline Avocado peel & Strong antioxidant activity & $\begin{array}{l}\text { Production of nutraceuticals and colouring } \\
\text { agents }\end{array}$ & (Wang et al., 2010) \\
\hline
\end{tabular}


Dried peels of avocado were used to produce a novel functional beverage. The tea produced from avocado peel was similar to mate tea having a high level of phenolic compounds with no significantly difference during the storage (Rotta et al., 2016). The production of natural food preservatives is of great interest because the demand of food consumers for healthy products has been increasing (Mark et al., 2019). The avocado peel extract has been used to inhibit lipid and protein oxidation and to avoid colour deterioration of meat products, which make the peel as a potential natural food grade preservative (Rodríguez-Carpena et al., 2011).

Avocado peel extract was used to inhibit the release of the pro-inflammatory TNF- $\alpha$ and the inflammation mediator nitric oxide, probably due to its much phenolic compounds and antioxidant capacity (Tremocoldi et al., 2018). Furthermore, avocado peel extract has been proved to have higher radical scavenging and antioxidant activity than nisin, a natural antimicrobial dipeptide. In addition to this, peel extract had a remarkable antimicrobial effect on Listeria innocua (ATCC 33090), Escherichia coli (JMP101), Lactobacillus sakei, Weissella viridescens and Leuconostoc mesenteroides. The highest antimicrobial activity against $L$. innocua was reached with $61 \%$ of peel extract and $39 \%$ of nisin (Calderón-Oliver et al., 2016).

Some research proved that avocado peel has potential for the production of activated carbon to reduce the chemical and biological oxygen demand of coffee processing wastewater. Avocado peel activated carbon (APC) is reported to be a promising cheaper alternative to high-priced activated carbon as the adsorption capacity of APC was comparable to the commercial ones. Additionally, the quality of water treated with APC was convenient for irrigation and straight discharge to the water sources (Devi et al., 2008). Avocado peel is also studied to produce ecology-friendly adsorbents for the removal of basic and acidic dyes as a promising alternative to conventional activated carbons. The optimum conditions for the process were determined using the application of factorial design and response surface methodology as $900^{\circ} \mathrm{C}$ for carbonisation temperature at $65 \mathrm{~min}$. Carbonised avocado peel is a promising adsorbent for various dyes removal due to its low cost and wide availability of the raw material along with the satisfying adsorption capacity (Palma et al., 2016).

\section{Conclusions}

Avocado is a worldwide cultivated and consumed fruit which is popular because of its nutritious bioactive composition and many health benefits. Avocado peel is a significant part of avocado as it can be exploited to produce food ingredients due to its rich content of high biological activity. The demand for avocado, is increasing year by year. Processing of avocado produces considerable amount of by-products, which represents multiple environmental problems. As a cheap and easily attainable raw material, avocado peel can be used for production of natural food additives, pharmaceuticals, medicines and nature-friendly adsorbents.

Future studies on avocado peel should be more comprehensive to identify the individual phenolic components and detect new compounds by application of more suitable extraction, isolation and characterisation techniques. Moreover, health benefits and potential applications of individual compounds obtained from avocado peel need additional in-depth research. In brief, the usage of avocado peel as an inexpensive and rich source of phytochemicals depends on 2 descriptive further aspects: (a) cost-efficient and effective recovering methods for phenolic compounds; (b) the potential usage of phenolic compounds as functional ingredients in food, medicine and pharmaceutical products.

\section{Compliance with Ethical Standard}

Conflict of interests: The authors declare that for this article they have no actual, potential or perceived the conflict of interests.

Ethics committee approval: The authors declare that this study does not require ethical permission.

Funding disclosure: -

Acknowledgments: -

Disclosure: - 


\section{References}

Adikaram, N.K.B., Ewing, D.F., Karunaratne, A.M., \& Wijeratne, E.M. (1992). Antifungal compounds from immature avocado fruit peel. Phytochemistry, 31(1), 93-96. https://doi.org/10.1016/0031-9422(91)83013-B

Ahangarpour, A., Sayahi, M., Sayahi, M. (2019). The antidiabetic and antioxidant properties of some phenolic phytochemicals: A review study. Diabetes \& Metabolic Syndrome: Clinical Research \& Reviews, 13(1), 854-857.

https://doi.org/10.1016/j.dsx.2018.11.051

Álvarez, S.P., Quezada, G. Á., Arbelo, O.C. (2015). Avocado (Persea americana Mill). Cultivos Tropicales, 36(2), 111-123.

Antasionasti, I., Riyanto, S., Rohman, A. (2017). Antioxidant activities and phenolics contents of avocado (Persea americana Mill.) peel in vitro. Research Journal of Medicinal Plant, 11(2), 55-61.

https://doi.org/10.3923/rjmp.2017.55.61

Araújo, R.G., Rodriguez-Jasso, R.M., Ruiz, H.A., Pintado, M.M.E., Aguliar, C.N. (2018). Avocado by-products: Nutritional and functional properties. Trends in Food Science \& Technology, 80, 51-60.

https://doi.org/10.1016/j.tifs.2018.07.027

Bayram, S. (2005). Bazı avocado çeşitlerinde hasat zamanını belirlemek için fizyolojik parametrelerin kullanılması (Using of physiological parameters in some avocado cultivars to determinate harvest date). Süleyman Demirel University, Master Thesis, Graduate School of Natural and Applied Sciences, $53 \mathrm{p}$.

Bowen, J., Billing, D., Connolly, P., Smith, W., Cooney, J., Burdon, J. (2018). Maturity, storage and ripening effects on anti-fungal compounds in the skin of 'Hass' avocado fruit. Postharvest Biology and Technology, 146, 43-50.

https://doi.org/10.1016/j.postharvbio.2018.08.005

Calderón-Oliver, M., Escalona-Buendía, H.B., MedinaCampos, O.N., Pedraza-Chaverri, J., Pedroza-Islas, R., \& Ponce-Alquicira, E. (2016). Optimization of the antioxidant and antimicrobial response of the combined effect of nisin and avocado byproducts. LWT-Food Science and Techno$\log y, 65,46-52$.

https://doi.org/10.1016/j.lwt.2015.07.048

Colombo, R., Papetti, A. (2019). Avocado (Persea americana Mill.) by-products and their impact: from bioactive compounds to biomass energy and sorbent material for removing contaminants. A review. International Journal of Food Science \& Technology, 54(4), 943-951.

https://doi.org/10.1111/ijfs.14143

Coman, V., Teleky, B., Mitrea, L., Martău, G.A., Szabo, K., Călinoiu, L., Vodnar, D.C. (2020). Bioactive potential of fruit and vegetable wastes. Advances in Food and Nutrition Research, 91, 157-225.

https://doi.org/10.1016/bs.afnr.2019.07.001

Devi, R., Singh, V., Kumar, A. (2008). COD and BOD reduction from coffee processing wastewater using Avacado peel carbon. Bioresource Technology, 99, 1853-1860.

https://doi.org/10.1016/j.biortech.2007.03.039

FAOSTAT (2017). FAO statistical database (FAOSTAT). http://www.fao.org/faostat/en/\#data/QC Retrieved 2020 May $15,2020$.

FAOSTAT (2018). FAO statistical database (FAOSTAT). http://www.fao.org/faostat/en/\#data/QC Retrieved 2020 July 17, 2020.

Figueroa, J.G., Borrás-Linares, I., Lozano-Sánchez, J., Segura-Carretero, A. (2018). Comprehensive identification of bioactive compounds of avocado peel by liquid chromatography coupled to ultra-high-definition accurate-mass QTOF. Food Chemistry, 245, 707-716.

https://doi.org/10.1016/j.foodchem.2017.12.011

Golukcu, M., Ozdemir, F. (2010). Changes in phenolic composition of avocado cultivars during harvesting time. Chemistry of Natural Compounds, 46(1), 112-115. https://doi.org/10.1007/s10600-010-9541-5

Hurtado-Fernández, E., Fernández-Gutiérrez, A., Carrasco-Pancorbo, A. (2018). Avocado fruit-Persea americana. In: Rodrigues, S., Silva, Ede S. Brito, E.Sde. (Eds.). Exotic Fruits Reference Guide. Elsevier-Academic Press, 
London.

https://doi.org/10.1016/B978-0-12-803138-4.00001-0

Karasawa, M.M.G., Mohan, C. (2018). Fruits as prospective reserves of bioactive compounds: A review. Natural Products and Bioprospecting, 8, 335-346.

https://doi.org/10.1007/s13659-018-0186-6

Kosińska, A., Karamać, M., Estrella, I., Hernández, T., Bartolomé, B., Dykes, G.A. (2012). Phenolic compound profiles and antioxidant capacity of Persea americana Mill. peels and seeds of two varieties. Journal of Agricultural and Food Chemistry, 60(18), 4613-4619.

https://doi.org/10.1021/jf300090p

Lin, D., Xiao, M., Zhao, J., Li, Z., Xing, B., Li, X., Kong, M., Li, L., Zhang, Q., Liu, Y., Chen, H., Qin, W., Wu, H., \& Chen, S. (2016). An overview of plant phenolic compounds and their importance in human nutrition and management of type 2 diabetes. Molecules, 21(10), 1374.

https://doi.org/10.3390/molecules 21101374

López-Cobo, A., Gómez-Caravaca, A.M., Pasini, F., Caboni, M.F., Segura-Carretero, A., Fernández-Gutiérrez, A. (2016). HPLC-DAD-ESI-QTOF-MS and HPLCFLD-MS as valuable tools for the determination of phenolic and other polar compounds in the edible part and by-products of avocado. LWT - Food Science and Technology, 73, 505513.

https://doi.org/10.1016/j.lwt.2016.06.049

Lu, Q., Arteaga, J.R., Zhang, Q., Huerta, S., Go, V.L.W., Heber, D. (2005). Inhibition of prostate cancer cell growth by an avocado extract: role of lipid-soluble bioactive substances. Journal of Nutritional Biochemistry, 16(1), 23-30.

https://doi.org/10.1016/j.jnutbio.2004.08.003

Mardigan, L.P., Santos, V.J.dos., Silva, P.T.da., Visentainer, J.V., Gomes, S.T.M., Matsushita, M. (2018). Investigation of bioactive compounds from various avocado varieties (Persea americana Miller). Food Science and Technology, 39(1), 1-7.

https://doi.org/10.1590/fst.34817
Mark, R., Lyu, X., Lee, J.J.L., Parra-Saldívar, R., \& Chen, W.N. (2019). Sustainable production of natural phenolics for functional food applications. Journal of Functional Foods, 57, 233-254.

https://doi.org/10.1016/j.jff.2019.04.008

Melgar, B., Dias, M.I., Ciric, A., Sokovic, M., Garcia-Castello, E.M., Rodrigues-Lopez, A.D., Barros, L., Ferreira, I.C.R.F. (2018). Bioactive characterization of Persea americana Mill. by-products: A rich source of inherent antioxidants. Industrial Crops and Products, 111, 212-218.

https://doi.org/10.1016/j.indcrop.2017.10.024

Migliore, G., Farina, V., Dara Guccione, G., Schifani, G. (2018). Quality determinants of avocado fruit consumption in Italy. Implications for small farms. Food Safety Management, 19(163), 148-153.

Morais, D.R., Rotta, E.M., Sargi, S.C., Schmidt, E.M., Bonafe, E.G., Eberlin, M.N., Sawaya, A.C.H.F., \& Visentainer, J.V. (2015). Antioxidant activity, phenolics and UPLCESI(-)-MS of extracts from different tropical fruits parts and processed peels. Food Research International, 77, 392-399. https://doi.org/10.1016/j.foodres.2015.08.036

Ortiz-Viedma, J., Rodriguez, A., Vega, C., Osorio, F., Defillipi, B., Ferraira, R., Saavedra, J. (2018). Textural, flow and viscoelastic properties of Hass avocado (Persea americana Mill.) during ripening under refrigeration conditions. Journal of Food Engineering, 219, 62-70.

https://doi.org/10.1016/j.jfoodeng.2017.09.014

Ozdemir, F., Topuz, A. (2004). Changes in dry matter, oil content and fatty acids composition of avocado during harvesting time and post-harvesting ripening period. Food Chemistry, 86(1), 79-83.

https://doi.org/10.1016/j.foodchem.2003.08.012

Palma, C., Lloret, L., Puen, A., Tobar, M., Contreras, E. (2016). Production of carbonaceous material from avocado peel for its application as alternative adsorbent for dyes removal. Chinese Journal of Chemical Engineering, 24(4), 521-528.

https://doi.org/10.1016/j.cjche.2015.11.029

Permal, R., Chang, W.L., Seale, B., Hamid, N., \& Kam, R. (2020). Converting industrial organic waste from the cold- 
pressed avocado oil production line into a potential food preservative. Food Chemistry, 306, 125635.

https://doi.org/10.1016/j.foodchem.2019.125635

Rodríguez-Carpena, J.G., Morcuende, D., Estévez, M. (2011). Avocado by-products as inhibitors of colour deterioration and lipid and protein oxidation in raw porcine patties subjected to chilled storage. Meat Science, 89(2), 166-173. https://doi.org/10.1016/j.meatsci.2011.04.013

Rotta, E.M., Morais, D.R.de., Biondo, P.B.F., Santos, V.J.dos., Matsushita, M., Visentainer, J.V. (2016). Use of avocado peel (Persea americana) in tea formulation: a functional product containing phenolic compounds with antioxidant activity. Acta Scientiarum-Technology, 38(1), 23-29. https://doi.org/10.4025/actascitechnol.v38i1.27397

Saavedra, J., Córdova, A., Navarro, R., Díaz-Calderón, P., Fuentealba, C., Astudillo-Castro, C.Toledo, L., Enrione, J., \& Galvez, L. (2017). Industrial avocado waste: Functional compounds preservation by convective drying process. Journal of Food Engineering, 198, 81-90.

https://doi.org/10.1016/j.jfoodeng.2016.11.018

Sagar, N.A., Pareek, S., Sharma, S., Yahia, E.M., \& Lobo, M.G. (2018). Fruit and vegetable waste: bioactive compounds, their extraction, and possible utilization. Comprehensive Reviews in Food Science and Food Safety, 17(3), 512531.

https://doi.org/10.1111/1541-4337.12330
Shodehinde, S.A., Oboh, G. (2013). Antioxidant properties of aqueous extracts of unripe Musa paradisiaca on sodium nitroprusside induced lipid peroxidation in rat pancreas in vitro. Asian Pacific Journal of Tropical Biomedicine, 3(6), 449-457.

https://doi.org/10.1016/S2221-1691(13)60095-7

Tremocoldi, M.A., Rosalen, P.L., Franchin, M., Massarioli, A.P., Denny, C., Daiuto, É.R., J.A.R., Melo, P.S., \& de Alencar, S.M. (2018). Exploration of avocado by-products as natural sources of bioactive compounds. PLoS One, 13(2), e0192577.

https://doi.org/10.1371/journal.pone.0192577

Vinha, A.F., Moreira, J., Barreira, S.V.P. (2013). Physicochemical parameters, phytochemical composition and antioxidant activity of the Algarvian avocado (Persea americana Mill.). Journal of Agricultural Science, 5(12), 100-109. https://doi.org/10.5539/jas.v5n12p100

Wang, W., Bostic, T.R., Gu, L. (2010). Antioxidant capacities, procyanidins and pigments in avocados of different strains and cultivars. Food Chemistry, 122(4), 1193-1198. https://doi.org/10.1016/j.foodchem.2010.03.114

Yahia, E.M., Woolf, A.B. (2011). Avocado (Persea americana Mill.). In: Postharvest Biology and Technology of Tropical and Subtropical Fruits. Woodhead Publishing Limited, Cambridge.

https://doi.org/10.1533/9780857092762.125 